BOSCATTO, Muriele de Conto; MOSENA, Maurício. Decisão judicial democrática: o caminho entre o dever fundamental à fundamentação democrática e o direito fundamental à resposta constitucionalmente adequada ou hermeneuticamente desvelada. Revista Eletrônica Direito e Política, Programa de Pós-Graduação Stricto Sensu em Ciência Jurídica da UNIVALI, Itajaí, v.10, n.3, $2^{\circ}$ quadrimestre de 2015. Disponível em: www.univali.br/direitoepolitica - ISSN 1980-7791.

\title{
DECISÃO JUDICIAL DEMOCRÁTICA: O CAMINHO ENTRE O DEVER FUNDAMENTAL À FUNDAMENTAÇÃO DEMOCRÁTICA E O DIREITO FUNDAMENTAL À RESPOSTA CONSTITUCIONALMENTE ADEQUADA OU HERMENEUTICAMENTE DESVELADA
}

\author{
JUDICIAL DEMOCRATIC DECISION: THE WAY BETWEEN THE DUTY TO
}

FUNDAMENTAL DEMOCRATIC RATIONALE AND FUNDAMENTAL RIGHT TO

REPLY constitutionally ADEQUATE OR hermeneutically UNVEILED

\author{
Muriele de Conto Boscatto ${ }^{1}$ \\ Maurício Mosena²
}

SUMÁRIO: Introdução; 1 . Teoria dos direitos e deveres fundamentais para a caracterização do dever fundamental à fundamentação democrática e do direito fundamental à resposta constitucionalmente adequada (correta): ponto de partida à "decisão democrática"; 2. Da Crítica Hermenêutica do Direito: o "modus operandi" à realização do dever fundamental de fundamentação democrática e do direito à resposta constitucionalmente adequada (correta): percurso à "decisão democrática"; 3. Da concretização do direito fundamental a uma resposta constitucionalmente adequada ou hermeneuticamente desvelada: ponto de chegada à decisão democrática; Considerações finais. Referências das Fontes Citadas.

\section{RESUMO}

O presente estudo revela a preocupação com a temática da "decisão judicial democrática", a qual pressupõe o reconhecimento prévio, em atenção aos requisitos de validade do ato, no âmbito do Estado Democrático de Direito, dos dever fundamental à fundamentação democrática e direito fundamental à resposta constitucionalmente adequada. A teoria dos direitos fundamentais confere a nota de fundamentalidade a estes deveres e direitos fundamentais, dando a normatividade necessária às respectivas aplicações. Já a Crítica Hermenêutica do Direito revela o como se implementa e se realiza estes dever e direitos fundamentais, que representam face de uma mesma moeda, na superação do voluntarismo na decisão, próprio do subjetivismo do sujeito que assujeita o objeto - ou que decide conforme a sua consciência. A fundamentação democrática conduz à resposta constitucionalmente adequada.

\footnotetext{
${ }^{1}$ Mestranda em Direito pela Faculdade Meridional IMED - Passo Fundo/RS.

${ }^{2}$ Mestrando em Direito pela Faculdade Meridional IMED - Passo Fundo/RS.
} 
BOSCATTO, Muriele de Conto; MOSENA, Maurício. Decisão judicial democrática: o caminho entre o dever fundamental à fundamentação democrática e o direito fundamental à resposta constitucionalmente adequada ou hermeneuticamente desvelada. Revista Eletrônica Direito e Política, Programa de Pós-Graduação Stricto Sensu em Ciência Jurídica da UNIVALI, Itajaí, v.10, n.3, $2^{\circ}$ quadrimestre de 2015. Disponível em: www.univali.br/direitoepolitica - ISSN 1980-7791.

PALAVRAS-CHAVE: Direitos fundamentais; Estado Democrático de Direito; Hermenêutica.

ABSTRACT: This study reveals the concern with the theme of "democratic judicial decision", which presupposes the prior recognition, in attention to requi act the validity ments under the law of a democratic state, the fundamental duty to state reasons democratic and fundamental right to cons-titucionalmente appropriate response. The theory of fundamental rights gives the note of fundamentality to these fundamental duty and right, giving the normativity needed their applications. Already the Law Hermeneutics Review reveals how to implement and performs these duty and fundamental rights, which represit face of the same coin, in overcoming voluntarism in the decision, pro prio the subject of subjectivism as subject the object - or to decide according to their conscience. The democratic reasoning leads to the proper constitutional-mind response.

KEYWORDS: Fundamental rights; Democratic rule of law; Hermeneutics.

\section{INTRODUÇÃo}

A temática envolta do estudo a que nos dedicaremos nas linhas seguintes gira em torno da decisão judicial democrática, a qual pressupõe o reconhecimento dos dever fundamental de fundamentação democrática e direito fundamental à resposta correta, que, para o contexto do trabalho, se identifica com a resposta constitucionalmente adequada ou hermeneuticamente desvelada.

Nos questionaremos, especialmente, sobre a presença destes dever e direito fundamentais, na ótica da teoria dos direitos fundamentais, aplicada ao constitucionalismo pátrio e, assim, à perspectiva do Estado Democrático de Direito. A partir dessa resposta, nos investiremos sobre o que consiste, ou seja, como se realiza estes dever e direitos fundamentais, sempre no âmbito do paradigma constitucional.

Para desenvolver esta problemática, começaremos pela seara da teoria dos direitos e deveres fundamentais, apresentando a interrelacionalidade dos conceitos de democracia, de Estado Democrático de Direito, constitucionalismo e direitos fundamentais. Abordaremos a perspectiva da nota de fundamentalidade formal e material dos direitos fundamentais, para avançar na normatividade dos deveres e direitos fundamentais que exaltaremos. 
BOSCATTO, Muriele de Conto; MOSENA, Maurício. Decisão judicial democrática: o caminho entre o dever fundamental à fundamentação democrática e o direito fundamental à resposta constitucionalmente adequada ou hermeneuticamente desvelada. Revista Eletrônica Direito e Política, Programa de Pós-Graduação Stricto Sensu em Ciência Jurídica da UNIVALI, Itajaí, v.10, n.3, $2^{\circ}$ quadrimestre de 2015. Disponível em: www.univali.br/direitoepolitica - ISSN 1980-7791.

Assim chegando, passaremos à análise da Crítica Hermenêutica do Direito, como "caminho" apto para responder ao dever fundamental de fundamentação democrática e, nessa mesma medida, à busca e realização do correlato direito fundamental à resposta constitucionalmente adequada ou hermeneuticamente desvelada.

Nesse passo, presente estará a discussão sobre o paradigma constitucional em cotejo (ou confronto) com o "neoconstitucionalismo" e seus entraves, fazendo com que o debate entre Hebert Hart e Ronald Dworkin, bem como a ponderação alexyana e ainda o "pan-principiologismo" sejam enfrentamentos pontuais.

Do mesmo modo - ou principal e decorrentemente -, que a discricionariedade e o decisionismo, que se manifestam via voluntarismo judicial, determinantes da permanência da relação sujeito-objeto, também perspectivarão o debate, já em sua linha de frente, juntamente com a hermenêutica (ou melhor, com a Crítica Hermenêutica do Direito) como proposta à superação paradigmática e a realização dos deveres e direitos fundamentais oriundos da fundamentação democrática que, ao fim e ao cabo, estarão na base do estudo.

Por último, nos debruçaremos no direito fundamental à resposta correta ou à constitucionalmente adequada, apresentando, mais outra vez, a Crítica Hermenêutica do Direito, para o desvelar dessa conclusão.

Nessa medida, retomaremos a construção encima da fundamentação democrática, afastando a escolha subjetiva do intérprete do sentido do texto, à decisão democrática ou à resposta correta que buscamos. Enfatizaremos, outrossim, a responsabilidade política do julgador, que se manifesta pelo seu dever fundamental de fundamentação, resgatando a história jurídico-institucional do direito envolvido - ou seja, prestigiando a tradição hermenêutica -, para, após, confrontando-a ao texto constitucional, conduzir à construção da solução jurídica a esta adequada.

Sob estas premissas, então, e sob a base da fenomenologia hermenêutica, se passará o estudo a seguir problematizado. 
BOSCATTO, Muriele de Conto; MOSENA, Maurício. Decisão judicial democrática: o caminho entre o dever fundamental à fundamentação democrática e o direito fundamental à resposta constitucionalmente adequada ou hermeneuticamente desvelada. Revista Eletrônica Direito e Política, Programa de Pós-Graduação Stricto Sensu em Ciência Jurídica da UNIVALI, Itajaí, v.10, n.3, $2^{\circ}$ quadrimestre de 2015. Disponível em: www.univali.br/direitoepolitica - ISSN 1980-7791.

1 TEORIA DOS DIREITOS E DEVERES FUNDAMENTAIS PARA A CARACTERIZAÇÃO DO DEVER FUNDAMENTAL À FUNDAMENTAÇÃO DEMOCRÁTICA E DO DIREITO FUNDAMENTAL À RESPOSTA CONSTITUCIONALMENTE ADEQUADA (CORRETA): PONTO DE PARTIDA À "DECISÃO DEMOCRÁTICA"

Considerando a nossa perspectiva final, que se situa no questionamento a respeito da existência de um dever fundamental de fundamentação da decisão e num direito fundamental à "resposta correta", inclusive, como ponto de partida ao que optamos por chamar de "decisão judicial democrática", urge iniciarmos nosso trabalho evidenciando a relação entre direitos fundamentais e o Estado Democrático de Direito, bem como ainda entre direitos fundamentais e a democracia, para, após, evoluirmos à condição de fundamentalidade do dever e do direito que trabalhamos.

Sarlet ${ }^{3}$ destaca a estreita relação entre a concepção de direitos fundamentais e Estado Democrático de Direito, asseverando que aqueles, conjuntamente com a forma de Estado, do sistema de governo e da organização do poder, representam a essência do Estado constitucional, se apresentando como parâmetro de legitimidade ao mesmo tempo formal e material da ordem jurídica estatal. É, nesse contexto, que passam a ser considerados, para além da sua função originária de instrumento de defesa de liberdades individuais, como elementos da ordem jurídica objetiva, integrando um sistema axiológico que atua como fundamento material do ordenamento jurídico.

A doutrina lusitana de Queiroz ${ }^{4}$ tem a mesma preocupação. Primeiro, estreitando a concepção de Constituição à base e fundamento do Estado, erigindo-se, a partir daí, como modelo direto para toda atividade público-estatal, para, após, vincular os direitos fundamentais a esta ideia de Constituição, contextualizando:

\footnotetext{
3 SARLET, Ingo Wolfgang. A eficácia dos direitos fundamentais: uma teoria geral dos direitos fundamentais na perspectiva constitucional. 11 ed. rev. atual. Porto Alegre: Livraria do Advogado Editora, 2012, p. 141-208.

${ }^{4}$ QUEIROZ, Cristina M. M. Direitos fundamentais: teoria geral. 2 ed. Coimbra: Coimbra Editora, 2010, p. 74.
} 
BOSCATTO, Muriele de Conto; MOSENA, Maurício. Decisão judicial democrática: o caminho entre o dever fundamental à fundamentação democrática e o direito fundamental à resposta constitucionalmente adequada ou hermeneuticamente desvelada. Revista Eletrônica Direito e Política, Programa de Pós-Graduação Stricto Sensu em Ciência Jurídica da UNIVALI, Itajaí, v.10, n.3, $2^{\circ}$ quadrimestre de 2015. Disponível em: www.univali.br/direitoepolitica - ISSN 1980-7791.

Os direitos fundamentais são direitos constitucionais, que não devem em primeira linha ser compreendidos numa dimensão "técnica" de limitação do poder do Estado. Devem antes ser compreendidos e inteligidos como elementos definidores e legitimadores de toda ordem jurídica positiva. Proclamam uma "cultura jurídica" e "política" determinada, numa palavra, um concreto e objectivo "sistema de valores" ${ }^{\prime \prime}$.

Mais adiante no seu texto, Queiroz ${ }^{6}$ sinala que a proteção jurídica dos direitos fundamentais é agora uma proteção constitucional, porque assim exige o princípio do Estado Democrático de Direito, sendo que as constantes mutações das situações típicas de perigo exigem uma defesa móvel, flexível e aberta desses direitos.

Afora a íntima relação que já se estabelece pelo próprio reconhecimento de determinados direitos fundamentais afetos à realização da democracia, no constitucionalismo pátrio (como as liberdades e os direitos políticos), a principal vinculação entre eles se dá pela função decisiva dos direitos fundamentais como garantia das minorias contra eventuais desvios de poder praticados pela maioria que está no poder. Quer dizer, pelo papel contramajoritário outorgado aos direitos fundamentais.

A democracia só existe por e para a realização dos direitos fundamentais, permitindo que estes se imponham sobre o próprio poder constituído, ainda que democraticamente legitimado.

Novais, num único parágrafo, correlaciona os conceitos:

[...] na declaração dos Direitos do Homem e do Cidadão da Revolução Francesa, Constituição é separação de poderes e direitos fundamentais; mas, no Estado de Direito material dos nossos dias, deve haver a consciência da instrumentalidade do primeiro princípio, a separação dos poderes, relativamente aos segundos, os direitos fundamentais ${ }^{7}$.

\footnotetext{
${ }^{5}$ QUEIROZ, Cristina M. M. Direitos fundamentais: teoria geral. 2 ed. Coimbra: Coimbra Editora, 2010, p. 49.

${ }^{6}$ QUEIROZ, Cristina M. M. Direitos fundamentais: teoria geral. 2 ed. Coimbra: Coimbra Editora, 2010, p. 74.

7 NOVAIS, Jorge Reis. Direitos fundamentais e justiça constitucional em estado democrático de direito. $1^{\text {a }}$ ed. Coimbra: Coimbra Editora, 2012, p. 203.
} 
BOSCATTO, Muriele de Conto; MOSENA, Maurício. Decisão judicial democrática: o caminho entre o dever fundamental à fundamentação democrática e o direito fundamental à resposta constitucionalmente adequada ou hermeneuticamente desvelada. Revista Eletrônica Direito e Política, Programa de Pós-Graduação Stricto Sensu em Ciência Jurídica da UNIVALI, Itajaí, v.10, n.3, $2^{\circ}$ quadrimestre de 2015. Disponível em: www.univali.br/direitoepolitica - ISSN 1980-7791.

Assim é que, nos dizeres de Sarlet, fazendo referência a Hans-P Schneider, "os direitos fundamentais [...] podem ser considerados [...] conditio sine qua non do Estado Constitucional Democrático" ${ }^{\prime 8}$. Nessa medida, o reconhecimento de um direito/dever fundamental de fundamentação democrática da decisão determina que tal motivação - a qual, como adiante veremos, se identifica com a resposta constitucionalmente adequada ou hermeneuticamente desvelada ou o direito fundamental a resposta correta - é pressuposto de validade da decisão judicial, nos parâmetros do Estado Democrático de Direito.

Introduzida a abordagem inicial acerca da relação entre os direitos fundamentais e os alicerces do constitucionalismo pátrio, Estado (Democrático) de Direito e democracia, nossa preocupação passa ser a fundamentalidade do dever de fundamentação (motivação) democrática da decisão judicial e do direito à resposta correta.

Caracteriza o catálogo de direitos fundamentais da Constituição Federal de 1988, previsto no seu Título II, nominado "Dos Direitos e Garantias Fundamentais", a sua natureza aberta. Quer dizer: o extenso rol do art. 50, donde constam a maioria dos direitos de defesa, os direitos sociais do art. 60, os direitos dos trabalhadores do art. 70 e os demais direitos assegurados nos arts. $8^{\circ}$ a 110 , todos da Constituinte de 1988, constituem um elenco meramente exemplificativo. Nessa medida, é que o $§ 2^{\circ}$, do art. $5^{\circ}$, da Constituição Federal de 1988 , contempla que

os direitos e garantias expressos nesta Constituição não excluem outros decorrentes do regime e dos princípios por ela adotados, ou dos tratados internacionais em que a República Federativa do Brasil seja parte.

Tal previsão determina a existência, no constitucionalismo pátrio, da fundamentalidade formal e material dos direitos e garantais que estudamos. Fala-se em fundamentalidade formal, relacionadamente ao direito constitucional positivo, sob três enfoques: um, por situarem-se os direitos fundamentais no ápice do

\footnotetext{
${ }^{8}$ SARLET, Ingo Wolfgang. A eficácia dos direitos fundamentais: uma teoria geral dos direitos fundamentais na perspectiva constitucional. $11 \mathrm{ed}$. rev. atual. Porto Alegre: Livraria do Advogado Editora, 2012, p. 59.
} 
BOSCATTO, Muriele de Conto; MOSENA, Maurício. Decisão judicial democrática: o caminho entre o dever fundamental à fundamentação democrática e o direito fundamental à resposta constitucionalmente adequada ou hermeneuticamente desvelada. Revista Eletrônica Direito e Política, Programa de Pós-Graduação Stricto Sensu em Ciência Jurídica da UNIVALI, Itajaí, v.10, n.3, $2^{\circ}$ quadrimestre de 2015. Disponível em: www.univali.br/direitoepolitica - ISSN 1980-7791.

ordenamento jurídico, cuidando-se de direitos supralegais; dois, por encontrarem-se submetidos a limites formais (procedimento agravado) e materiais (cláusulas pétreas) da reforma constitucional; e, três, por tratarem-se de normas diretamente aplicáveis e que vinculam de forma imediata as entidades públicas e privadas. A fundamentalidade material, por sua vez, decorre da circunstância de serem os direitos fundamentais elemento constitutivo da Constituição material, contendo decisões fundamentais sobre a estrutura básica do Estado e da sociedade.

A citada regra do direito constitucional positivo ( $\S 22^{\circ}$, do art. $5^{\circ}$, da $C F / 88$ ), ao trazer a noção de fundamentalidade material, é que permite, então, a abertura da Constituição à caracterização de outros direitos materialmente fundamentais que não constaram do seu texto ou ainda que foram contemplados fora do catálogo dos Direitos Fundamentais, insculpido no seu Título II. Portanto, desde já, cabe aferir que é desta regra do direito posto que encontramos o suporte normativo para a caracterização do dever de fundamentação da decisão judicial e do direito à resposta correta, como direito/dever fundamental e, nessa medida, como pressuposto de legitimidade para decisão, no contexto do Estado Democrático de Direito.

Segundo Sarlet,

Direitos fundamentais em sentido material são aqueles que, apesar de se encontrarem fora do catálogo, por seu conteúdo e por sua importância, podem ser equiparados aos direitos formalmente (e materialmente) fundamentais ${ }^{9}$.

Metodologicamente, a doutrina dividiu os direitos fundamentais em: direitos formal e materialmente fundamentais, ou seja, aqueles com suporte expresso no texto constitucional, seja no Título próprio, seja noutras partes do referido texto; e em direitos materialmente fundamentais, sendo aqueles não expressos em qualquer parte da Constituição Federal, mas ficando subentendidos ou decorrendo diretamente dos princípios e do regime, no caso brasileiro,

\footnotetext{
${ }^{9}$ SARLET, Ingo Wolfgang. A eficácia dos direitos fundamentais: uma teoria geral dos direitos fundamentais na perspectiva constitucional. 11 ed. rev. atual. Porto Alegre: Livraria do Advogado Editora, 2012, p. 80.
} 
BOSCATTO, Muriele de Conto; MOSENA, Maurício. Decisão judicial democrática: o caminho entre o dever fundamental à fundamentação democrática e o direito fundamental à resposta constitucionalmente adequada ou hermeneuticamente desvelada. Revista Eletrônica Direito e Política, Programa de Pós-Graduação Stricto Sensu em Ciência Jurídica da UNIVALI, Itajaí, v.10, n.3, $2^{\circ}$ quadrimestre de 2015. Disponível em: www.univali.br/direitoepolitica - ISSN 1980-7791.

contemplados pelo Título I, da Constituição Federal de $1988^{10}$, além dos previstos em tratados internacionais que o Brasil seja parte.

Trabalham-se com critérios para definição do conteúdo material do direito fundamental. Exemplificadamente, estaria o critério implícito da equivalência e seu significado, que quer dizer que qualquer direito que assim queria ser considerado de fundamentalidade material - seja implícito ou subentendido; seja decorrente do regime ou dos princípios; ou seja ainda contemplado por algum tratado internacional do qual o Brasil seja parte -, para ser considerado como tal, deverá equivaler, em seu conteúdo e dignidade, aos direitos fundamentais previstos no catálogo. A opção do Constituinte, ao erigir certa matéria à categoria de direito fundamental, provém da efetiva importância que possui para a comunidade em determinado momento histórico, circunstância esta que tornase indispensável à caracterização da posição jurídica de fundamentalidade material.

Afora outros, também seria o caso, na linha de Sarlet ${ }^{11}$, da referência de fundo dos direitos fundamentais ao princípio da dignidade da pessoa humana. Os critérios são distintos e corelatos à ordem constitucional positiva, propiciando uma identificação constitucionalmente adequada e relativamente segura dos direitos materialmente fundamentais.

$\mathrm{Na}$ esteira de Queiroz $^{12}$ o que identifica o rol de direitos fundamentais é o fato de constituir a especificação jurídica de postulados filosóficos-políticos que caracteriza uma cultura jurídica particular, qual seja, o constitucionalismo.

\footnotetext{
${ }^{10}$ Vale destacar a existência de doutrina, advogando sobre uma terceira divisão, como sendo a dos direitos apenas formalmente fundamentais, a exemplo, dos posicionamentos de Canotilho (CANOTILHO, Joaquim José Gomes. Direito Constitucional e Teoria da Constituição. $3^{a}$ ed. Coimbra: Coimbra Editora, 1999) e José Carlos Vieira de Andrade (ANDRADE, José Carlos Vieira de. Os direitos fundamentais na constituição portuguesa de 1976. Coimbra: Livraria Almedina, 1987, apud SARLET, Ingo Wolfgang. A eficácia dos direitos fundamentais: uma teoria geral dos direitos fundamentais na perspectiva constitucional. 11 ed. rev. atual. Porto Alegre: Livraria do Advogado Editora, 2012). Estamos com Sarlet (SARLET, Ingo Wolfgang. A eficácia dos direitos fundamentais: uma teoria geral dos direitos fundamentais na perspectiva constitucional. 11 ed. rev. atual. Porto Alegre: Livraria do Advogado Editora, 2012, p. 80. 2012), no sentido de que todos os direitos que são formalmente fundamentais, assim também o são materialmente fundamentais.
}

${ }^{11}$ SARLET, Ingo Wolfgang. A eficácia dos direitos fundamentais: uma teoria geral dos direitos fundamentais na perspectiva constitucional. 11 ed. rev. atual. Porto Alegre: Livraria do Advogado Editora, 2012, p. 93-111.

${ }^{12}$ QUEIROZ, Cristina M. M. Direitos fundamentais: teoria geral. 2 ed. Coimbra: Coimbra Editora, 2010, p. 81. 
BOSCATTO, Muriele de Conto; MOSENA, Maurício. Decisão judicial democrática: o caminho entre o dever fundamental à fundamentação democrática e o direito fundamental à resposta constitucionalmente adequada ou hermeneuticamente desvelada. Revista Eletrônica Direito e Política, Programa de Pós-Graduação Stricto Sensu em Ciência Jurídica da UNIVALI, Itajaí, v.10, n.3, $2^{\circ}$ quadrimestre de 2015. Disponível em: www.univali.br/direitoepolitica - ISSN 1980-7791.

Todavia, mais outra vez, a tarefa consistente neste reconhecimento à posição jurídica de direito materialmente fundamental é algo que também compete ao Judiciário e, nessa medida, a discussão pontual sobre até onde pode ir a competência criativa do intérprete, no paradigma do Estado Democrático de Direito - e cuja preocupação nos dedicaremos abaixo, para demonstrarmos o caminho para resposta constitucionalmente adequada ou hermeneuticamente desvelada - torna-se a linha de frente também desta problemática.

É, assim, também, o ponto de vista de Queiroz $^{13}$, afirmando que os direitos fundamentais diferenciam-se dos meros direitos de defesa e dos simples deveres de omissão por parte do Estado, transformando-se em instrumento de proteção dinâmica do cidadão e da sociedade. As normas abertas da Constituição portanto, para além dos direitos fundamentais previstos no catálogo próprio da constituinte - deixam de identificarem-se como programas constitucionais, para projetarem-se na atividade jurisprudencial.

Vale antecipar o limite apontado por Sarlet nesta busca: a distribuição de competências no Estado Democrático de Direito, que não permite que o Judiciário substitua o legislador na sua atividade precípua de criação do direito, muito mais na seara constitucional. A tarefa do Judiciário, no campo da identificação e localização dos direitos fundamentais situados fora do catálogo, "é, acima de tudo, a de identificar e revelar o que já existe, ainda que de forma implícita $[\ldots]^{\prime 14}$.

Em qualquer caso, tratando-se de direitos escritos (presentes no texto constitucional, mas fora do Título II), ou de direitos não escritos (implícitos, decorrentes e previstos em tratados internacionais), a decisão jurídica que erige determinado direito à posição jurídica de materialmente fundamental pressupõe, obviamente, fundamentação, representando a própria exegese do dever e direito fundamentais cujo reconhecimento exaltamos: à fundamentação democrática e à resposta correta.

13 QUEIROZ, Cristina M. M. Direitos fundamentais: teoria geral. 2 ed. Coimbra: Coimbra Editora, 2010, p. 69.

${ }^{14}$ SARLET, Ingo Wolfgang. A eficácia dos direitos fundamentais: uma teoria geral dos direitos fundamentais na perspectiva constitucional. 11 ed. rev. atual. Porto Alegre: Livraria do Advogado Editora, 2012, p. 138. 
BOSCATTO, Muriele de Conto; MOSENA, Maurício. Decisão judicial democrática: o caminho entre o dever fundamental à fundamentação democrática e o direito fundamental à resposta constitucionalmente adequada ou hermeneuticamente desvelada. Revista Eletrônica Direito e Política, Programa de Pós-Graduação Stricto Sensu em Ciência Jurídica da UNIVALI, Itajaí, v.10, n.3, $2^{\circ}$ quadrimestre de 2015. Disponível em: www.univali.br/direitoepolitica - ISSN 1980-7791.

De mais a mais, o direito e o dever fundamentais que aqui chamamos atenção, ou seja, o dever fundamental à fundamentação e o direito fundamental à resposta correta, encontram amparo, assim como tal, no constitucionalismo pátrio, no art. 93, IX, da Constituição Federal de 1988. Na dicção do preceito constitucional, "todos os julgamentos dos órgãos do poder judiciário serão públicos, e fundamentadas todas as decisões, sob pena de nulidade [...]".

Nessa medida, o dever fundamental de fundamentação da decisão judicial e o seu consequente direito à resposta correta, no caso brasileiro, constituem-se com a nota de fundamentalidade formal, eis que expressos no texto da Constituição vigente, em que pese fora do catálogo do Título próprio, bem como material, na medida em que se afinam com os critérios para tal caracterização. Em especial, inclusive, fazendo a ligação com a abordagem que trazemos inicialmente à baila, podendo-se dizer correlatos ao regime democrático e, nessa medida, às diretrizes estruturais do Estado e da sociedade.

Não é demais ainda insistir que a importância de a fundamentação da decisão judicial e a resposta correta serem enquadradas na posição jurídica de direito/ dever fundamental reside no reconhecimento do idêntico regime jurídico, o que equivale a dizer, para o constitucionalismo brasileiro, aplicabilidade imediata ( $\S$ $1^{\circ}$, do art. 50, da CF/88) e a condição de cláusula pétrea, além de, é claro, consistir elemento para a validade da decisão, nos parâmetros do Estado Democrático de Direito, donde ficamos não apenas com a fundamentação ou a motivação, mas estendemos à característica de democrática, bem como não apenas com a resposta - ou com múltiplas respostas -, mas com a marca da correção.

Nos dizeres de Novais,

[...] direitos fundamentais constitucionais [...] não são mera proclamação retórica cuja realização se satisfaz com a sua entrega às boas intenções do Poder político e do legislador, mas são, antes, norma jurídica directamente aplicável, dotada de força constitucional que vincula todos os poderes do Estado, incluindo o legislador democrático, e cuja supremacia deve ser assegurada por um poder judicial 
BOSCATTO, Muriele de Conto; MOSENA, Maurício. Decisão judicial democrática: o caminho entre o dever fundamental à fundamentação democrática e o direito fundamental à resposta constitucionalmente adequada ou hermeneuticamente desvelada. Revista Eletrônica Direito e Política, Programa de Pós-Graduação Stricto Sensu em Ciência Jurídica da UNIVALI, Itajaí, v.10, n.3, $2^{\circ}$ quadrimestre de 2015. Disponível em: www.univali.br/direitoepolitica - ISSN 1980-7791.

funcionalmente independente da maioria política que ocupa conjunturalmente o poder $^{15}$.

Falamos, até aqui, mais de direitos do que de deveres fundamentais. Portanto, nos cabe ainda, nesta primeira abordagem, situar a perspectiva da fundamentação da decisão judicial como dever fundamental. Para tanto, Queiroz:

"[...] quando se afirma uma concepção 'constitucional' do Estado de Direito os direitos fundamentais surgem essencialmente valorados em termos da sua natureza deontológica, isto é, do seu caráter de 'deverosidade'"'16.

Os indivíduos não são apenas titulares de direitos fundamentais, assim também o são titulares de deveres jurídicos fundamentais. Nesse mesmo viés, o Estado também é incumbido de verdadeiras tarefas constitucionais, que representam seu dever constitucional de proteção. Nessa medida, as normas constitucionais cujo conteúdo contenha fundamentalidade não garantem apenas direitos subjetivos, como os de defesa e os prestacionais, mas ainda traduzem princípios objetivos básicos da ordem democrática e constitucional do Estado de Direito, donde se situa a fundamentação democrática da decisão.

Na esteira de Sarlet:

O reconhecimento de deveres fundamentais diz com a participação ativa dos cidadãos na vida pública e implica, na acepção de José Carlos Vieira de Andrade, "um empenho solidário de todos na transformação das estruturas sociais", portanto, reclama um mínimo de responsabilidade social no exercício da liberdade individual e implica a existência de deveres jurídicos (e não apenas morais) de respeito pelos valores constitucionais e pelos direitos fundamentais, inclusive, na esfera das relações entre privados, justificando, inclusive, limitações ao exercícios dos direitos fundamentais ${ }^{17}$.

15 NOVAIS, Jorge Reis. Direitos fundamentais e justiça constitucional em estado democrático de direito. $1^{a}$ ed. Coimbra: Coimbra Editora, 2012, p. 199.

${ }^{16}$ QUEIROZ, Cristina M. M. Direitos fundamentais: teoria geral. 2 ed. Coimbra: Coimbra Editora, 2010, p. 87-88.

17 SARLET, Ingo Wolfgang. A eficácia dos direitos fundamentais: uma teoria geral dos direitos fundamentais na perspectiva constitucional. 11 ed. rev. atual. Porto Alegre: Livraria do Advogado Editora, 2012, p. 228. 
BOSCATTO, Muriele de Conto; MOSENA, Maurício. Decisão judicial democrática: o caminho entre o dever fundamental à fundamentação democrática e o direito fundamental à resposta constitucionalmente adequada ou hermeneuticamente desvelada. Revista Eletrônica Direito e Política, Programa de Pós-Graduação Stricto Sensu em Ciência Jurídica da UNIVALI, Itajaí, v.10, n.3, $2^{\circ}$ quadrimestre de 2015. Disponível em: www.univali.br/direitoepolitica - ISSN 1980-7791.

$\mathrm{Na}$ teoria dos deveres fundamentais, o caso que se tornou paradigmático, notadamente, na Alemanha, para a noção do dever de proteção, foi o Lüth $^{18}$, pelo qual a Corte Constitucional Alemã precisou da noção de valores objetivos a fim de demonstrar que os direitos fundamentais não se caracterizariam apenas como instrumento de defesa do indivíduo contra o Estado. Ressalta Grimm ${ }^{19}$ que, nos anos que se seguiram a este caso paradigmático, a concepção dos valores objetivos serviu de base para determinados efeitos atribuídos aos direitos fundamentais, e o principal deles foi o Schutzpflicht ou dever de proteção.

O dever de proteção é visto como o outro lado dos direitos fundamentais. Fundado no dever maior de segurança, sendo esta a principal tarefa do Estado, se distribui em duas vertentes: a da proibição do excesso; e da proibição da proteção deficiente. Quer dizer: representa o maior espectro de alcance da proteção dos direitos fundamentais, seja através de abstenções ou negações, seja ainda mediante uma postura positiva, no sentido de impedir sejam vulnerados estes direitos e bens fundamentais, da parte de quem seja, Estado ou mesmo particular.

Portanto, em função do efeito relacionado ao dever de proteção, se pode dizer que os direitos fundamentais, além de instrumento a serviço do cidadão contra excessos do Estado, também caracterizam uma cadeia de deveres fundamentais,

\footnotetext{
${ }^{18}$ Viet Harlan, diretor de cinema do período nazista, reapareceu no cenário cinematográfico do pósguerra com o filme chamado Unsterbliche Geliebte (Amante Imortal). Erich Lüth, líder do clube de imprensa de Hamburgo e ativista engajado no esforço de reconciliação entre alemães e judeus, incitou os donos de cinemas a não exibir o filme de Harlan e os alemães a não assisti-lo, caso ele fosse exibido. As companhias cinematográficas intentaram uma medida judicial para impedir Lüth de repetir seu chamamento ao boicote. Ganharam respaldo da jurisprudência da época, porém, Lüth ingressou com uma Queixa Constitucional, na Corte Máxima, e invocou seu direito à liberdade de expressão, garantido no art. $5^{\circ}$ da Lei Fundamental Alemã. O argumento das companhias cinematográficas era justamente que os direitos fundamentais eram aplicáveis apenas nas relações entre o Estado e indivíduos. O cerne da questão era a aplicação tão-somente horizontal dos direitos fundamentais. Para responde-la, o Tribunal passou a dizer que os direitos fundamentais não são apenas direitos subjetivos do indivíduo contra o Estado, mas também expressão de valores objetivos. Chamou-se a isso de efeito irradiante dos direitos fundamentais. (GRIMM, Dieter. A função protetiva do Estado. In SOUZA NETO, Cláudio Pereira de. E SARMENTO, Daniel (Coord.). A constituição do direito: fundamentos teóricos e aplicações específicas. Rio de Janeiro: Lumen Juris, 2007, p. 149-165).

${ }^{19}$ GRIMM, Dieter. A função protetiva do Estado. In SOUZA NETO, Cláudio Pereira de. E SARMENTO, Daniel (Coord.). A constituição do direito: fundamentos teóricos e aplicações específicas. Rio de Janeiro: Lumen Juris, 2007, p. 149-165.
} 
BOSCATTO, Muriele de Conto; MOSENA, Maurício. Decisão judicial democrática: o caminho entre o dever fundamental à fundamentação democrática e o direito fundamental à resposta constitucionalmente adequada ou hermeneuticamente desvelada. Revista Eletrônica Direito e Política, Programa de Pós-Graduação Stricto Sensu em Ciência Jurídica da UNIVALI, Itajaí, v.10, n.3, $2^{\circ}$ quadrimestre de 2015. Disponível em: www.univali.br/direitoepolitica - ISSN 1980-7791.

donde se enquadra bem a noção de fundamentação democrática da decisão, como direito e dever fundamental, no paradigma do Estado Democrático de Direito.

No plano normativo-constitucional pátrio, é da Constituição Federal vigente, do seu Capítulo I, do Título II, ou seja, do rol dos direitos e garantias fundamentais, que se extrai a autorização legal (ou normativa) para o reconhecimento dos deve- res fundamentais, em especial, à fundamentação democrática da decisão (e por que não do seu correlato direito à resposta correta). Assim é que tal Capítulo expressa "Dos direitos e deveres individuais e coletivos".

Caracterizado o dever fundamental à fundamentação democrática da decisão judicial e o seu correspondente direito fundamental à resposta correta, no âmbito do Estado Democrático de Direito, como requisito inicial para aquilo que designamos de "decisão democrática" - própria deste paradigma constitucional -, nos cabe percorrer o "caminho" para o seu alcance, situando a discussão com o referencial da Crítica Hermenêutica do Direito, encabeçada, sobretudo, por Streck, em seus diversos textos.

\section{DA CRÍtICA HERMENÊUTICA DO DIREITO: O "MODUS OPERANDI" À} REALIZAÇÃO DO DEVER FUNDAMENTAL DE FUNDAMENTAÇÃO DEMOCRÁTICA E DO DIREITO À RESPOSTA CONSTITUCIONALMENTE ADEQUADA (CORRETA) - PERCURSO À "DECISÃO DEMOCRÁTICA"

Percorrer o caminho para a "decisão democrática" - que, após, veremos se identifica com a resposta constitucionalmente adequada ou hermeneuticamente desvelada ou, se assim se queria, com a resposta correta -, a partir da doutrina que veio a chamar-se de Crítica Hermenêutica do Direito, pressupõe seguir a abordagem a partir da concepção que hoje se tem a respeito de Estado de Democrático de Direito, o que determina falar-se do papel relegado ao Poder Judiciário à concretização dos direitos e deveres fundamentais e os limites que se deve manter nesta atividade. 
BOSCATTO, Muriele de Conto; MOSENA, Maurício. Decisão judicial democrática: o caminho entre o dever fundamental à fundamentação democrática e o direito fundamental à resposta constitucionalmente adequada ou hermeneuticamente desvelada. Revista Eletrônica Direito e Política, Programa de Pós-Graduação Stricto Sensu em Ciência Jurídica da UNIVALI, Itajaí, v.10, n.3, $2^{\circ}$ quadrimestre de 2015. Disponível em: www.univali.br/direitoepolitica - ISSN 1980-7791.

É sempre pontual a doutrina de Streck ${ }^{20}$, para quem o Estado Democrático de Direito representa mais do que uma classificação de Estado ou uma variante de sua evolução histórica, fazendo, sim, uma síntese das fases anteriores - ou seja, do Estado Liberal e do Estado Social (que não se teve propriamente no Brasil), nos quais a preocupação central, respectivamente, encontrava-se com o Legislativo e com o Executivo -, e acrescentando a construção de condições de possibilidades para suprir as lacunas destas etapas e fazer cumprir as promessas não alcançadas da modernidade, deslocando o locus da problemática para esfera judicial:

Desse modo, se, no paradigma liberal, o direito tinha a função meramente ordenadora, estando na legislação o ponto de tensão nas relações entre Estado-Sociedade, no modelo de Estado Social sua função passar a ser promovedora, estando apontadas as baterias para o Poder Executivo, pela exata razão da necessidade da realização das políticas do Welfare State. Já no Estado Democrático de Direito, fórmula constitucionalizada nos textos magnos das principais democracias, a função do direito passa a ser transformadora, onde o polo de tensão, em determinadas circunstâncias previstas nos textos constitucionais, passa para os Tribunais Constitucionais. E é evidente que isso gera(rá) problemas ${ }^{21}$.

Os problemas aventados por Streck são justamente os entraves das doutrinas que se construíram neste neoconstitucionalismo. Construções teóricas tais que, no objetivo de superar as dificuldades do modelo positivista normativista - o que explicaremos melhor adiante -, acabaram resvalando na mesma problemática. Para Streck, considerando o referencial teórico que adota, pautado na hermenêutica-filosófica, não teriam estas posturas teóricas superado o sujeito solipsista da modernidade, que assujeita o objeto, colocando a linguagem como terceira coisa entre o primeiro e o segundo ${ }^{22}$.

\footnotetext{
${ }^{20}$ STRECK, Lenio Luiz. Jurisdição constitucional e decisão jurídica. 3. ed. São Paulo: Revista dos Tribunais, 2013, p. 150-195.

${ }^{21}$ STRECK, Lenio Luiz. Jurisdição constitucional e decisão jurídica. 3. ed. São Paulo: Revista dos Tribunais, 2013, p. 168.

${ }^{22}$ STRECK, Lenio Luiz. Jurisdição constitucional e decisão jurídica. 3. ed. São Paulo: Revista dos Tribunais, 2013, 197-206.
} 
BOSCATTO, Muriele de Conto; MOSENA, Maurício. Decisão judicial democrática: o caminho entre o dever fundamental à fundamentação democrática e o direito fundamental à resposta constitucionalmente adequada ou hermeneuticamente desvelada. Revista Eletrônica Direito e Política, Programa de Pós-Graduação Stricto Sensu em Ciência Jurídica da UNIVALI, Itajaí, v.10, n.3, $2^{\circ}$ quadrimestre de 2015. Disponível em: www.univali.br/direitoepolitica - ISSN 1980-7791.

Na linha de Streck e Ferrajoli ${ }^{23}$, no Brasil, a importação do termo neoconstitucionalismo acabou gerando condições patológicas, terminando por incentivar ou institucionalizar uma recepção acrítica da jurisprudência dos valores, da teoria da argumentação jurídica de Robert Alexy, que cunhou o procedimento da ponderação como o instrumento pretensamente racionalizador da decisão judicial, e do ativismo judicial norte-americano.

[...] sob a bandeira "neoconstitucionalista" defende-se, ao mesmo tempo, um direito constitucional da efetividade; um direito assombrado pela ponderação de valores; uma concretização ad hoc da Constituição; e uma pretensa constitucionalização do ordenamento, a partir de jargões vazios de conteúdo e que reproduzem o prefixo neo em diversas ocasiões, tais como: neoprocessualismo (sic) e neopositivismo (sic). Tudo porque, ao fim e ao cabo, acreditou-se ser a jurisdição responsável pela incorporação dos "verdadeiros valores" que definem o direito justo $[\ldots]^{24}$.

Preferimos, então, traçar o momento histórico-político, no qual se inserem o direito e o dever fundamentais que fizemos alusão neste ensaio, seguindo o referencial streckiano, de Constitucionalismo Contemporâneo, caracterizado como "movimento teórico jurídico-político em que se busca limitar o exercício do poder a partir da concepção de mecanismos aptos a gerar e garantir o exercício da cidadania"25.

O neoconstitucionalismo fica a depender de posturas axiológicas e voluntaristas, que proporcionam atitudes incompatíveis com a democracia, como o ativismo e a discricionariedade judicial.

Nesse caminho, é que ganha relevo o célebre discurso entre Hebert Hart e Ronald Dworkin, ao discutirem sobre a suposta abertura do texto da norma, permitindo a discricionariedade do intérprete, para responder aquilo que o

23 STRECK, Lenio Luiz; FERRAJOLI, Luigui; e TRINDADE, André Karam (org). Garantismo, Hermenêutica e (neo)constitucionalismo: um debate com Luigui Ferrajoli. Porto Alegre: Livraria do Advogado, 2012.

24 STRECK, Lenio Luiz; FERRAJOLI, Luigui; e TRINDADE, André Karam (org). Garantismo, Hermenêutica e (neo)constitucionalismo: um debate com Luigui Ferrajoli. Porto Alegre: Livraria do Advogado, 2012, p. 62.

25 STRECK, Lenio Luiz; FERRAJOLI, Luigui; e TRINDADE, André Karam (org). Garantismo, Hermenêutica e (neo)constitucionalismo: um debate com Luigui Ferrajoli. Porto Alegre: Livraria do Advogado, 2012, p. 64. 
BOSCATTO, Muriele de Conto; MOSENA, Maurício. Decisão judicial democrática: o caminho entre o dever fundamental à fundamentação democrática e o direito fundamental à resposta constitucionalmente adequada ou hermeneuticamente desvelada. Revista Eletrônica Direito e Política, Programa de Pós-Graduação Stricto Sensu em Ciência Jurídica da UNIVALI, Itajaí, v.10, n.3, $2^{\circ}$ quadrimestre de 2015. Disponível em: www.univali.br/direitoepolitica - ISSN 1980-7791.

positivista chama de casos difíceis. Quer dizer, para Hart, os easy cases seriam resolvidos mediante dedução lógica ou método subsuntivo, já que o texto da norma teria a resposta da questão jurídica; e aos hard cases sobraria, então, o espaço para discricionariedade ou a criação do direito por parte do intérprete.

Dworkin repele esta discricionariedade hartiana, levantando bandeira a sua teoria integrativa, no sentido de que o intérprete não esta livre para julgar segundo a sua consciência - o que resgataria aquele paradigma superado da modernidade a que acima fizemos referência: o sujeito solipsista-, mas segue amarrado à sua responsabilidade política para com a história jurídicoinstitucional construída com as exigências do presente.

Para Dworkin, as partes do processo possuem o direito de que a solução jurídica para o caso esteja de acordo com o ordenamento previamente estabelecido (algo muito parecido com o que sustentamos por direito fundamental à resposta correta, inclusive, sendo proveniente desta doutrina a metáfora). Este, por sua vez, seria o fundamento para todos os casos, sejam fáceis ou difíceis, impedindo tanto a discricionariedade judicial, quanto o poder criativo dos juízes, defendidos por Hart.

Por outro lado, este ordenamento previamente estabelecido não é apenas composto por regras, mas, sobretudo, por princípios. Isto porque se reconhece que a sociedade é formada por pessoas que além de obedecerem às regras criadas pelo acordo político, reconhecem também princípios comuns como norteadores de suas ações. Todavia, em Dworkin, assim também em Streck e Ferrajoli, estes princípios não propiciam a suposta abertura interpretativa nos moldes apresentados por Hart e que, nessa medida, autorizaria a discricionariedade. Eles, sim, fechariam o sistema, vedando a discricionariedade ${ }^{26}$.

Enfim, é como o romance em cadeia, metáfora citada pelo próprio Dworkin, pelo qual o interprete deve manter a coerência na reconstrução da história. Nesse contexto, caminhando à construção da tese da resposta correta, segundo a qual o direito sempre teria (uma) resposta correta (assunto que nos debruçaremos melhor linhas abaixo). Noutros termos:

${ }^{26}$ Streck, Lenio. Lições de crítica hermenêutica do direito. 1 ed. Porto Alegre: Livraria do Advogado, 2014, p. 45-68. 
BOSCATTO, Muriele de Conto; MOSENA, Maurício. Decisão judicial democrática: o caminho entre o dever fundamental à fundamentação democrática e o direito fundamental à resposta constitucionalmente adequada ou hermeneuticamente desvelada. Revista Eletrônica Direito e Política, Programa de Pós-Graduação Stricto Sensu em Ciência Jurídica da UNIVALI, Itajaí, v.10, n.3, $2^{\circ}$ quadrimestre de 2015. Disponível em: www.univali.br/direitoepolitica - ISSN 1980-7791.

o direito como sistema de regras e princípios não abriria a possibilidade para um juízo discricionário, já que teria sempre uma história institucional a ser reconstruída e que indicaria a melhor decisão a ser tomada ${ }^{27}$.

Na perspectiva de Hart, múltiplas respostas seriam inerentes aos resultados dos casos difíceis. O sujeito solipsisita da modernidade permaneceria vivo, nada obstante a virada linguística proposta pela filosofia da linguagem, e as discricionariedades certamente caminhariam para arbitrariedades, distorcendo a concepção de Estado Democrático de Direito, para governo dos juízes. Portanto, a decisão que se fundamenta na discricionariedade e criatividade judicial não responde à fundamentação cuja nota de fundamentalidade defendemos e que constitui o caminho à "decisão democrática". Vale o jargão streckiano: "não se pode falar qualquer coisa, sobre qualquer coisa".

$\mathrm{Na}$ esteira de Streck,

[...] discutir as condições de possibilidade da decisão jurídica é, antes de tudo, uma questão de democracia. Por isso, deveria ser despiciendo acentuar ou lembrar que a crítica a discricionariedade judicial não é uma "proibição de interpretar". Ora, interpretar é dar sentido ("Sinngebung"). É fundir horizontes. E direito é um sistema de regras e princípios, "comandado" por uma Constituição. Assim, afirmar que as palavras da lei (lato sensu) contêm vaguezas e ambiguidades e que os princípios podem ser - e na maior parte das vezes são - mais "abertos" em termos de possibilidade de significado, não constitui novidade. O que deve ser entendido é que a realização/concretização desses textos (isto é, a sua transformação em normas) não depende de uma subjetividade assujeitadora (esquema sujeito-objeto), como se os sentidos a serem atribuídos fossem fruto da vontade do interprete, dando assim razão a Kelsen, para quem "a interpretação a ser feita pelos juízes é um ato de vontade" ${ }^{28}$.

27 Streck, Lenio. Lições de crítica hermenêutica do direito. 1 ed. Porto Alegre: Livraria do Advogado, 2014, p. 59.

${ }^{28}$ STRECK, Lenio. Jurisdição e ausência de uma teoria da decisão. Revista de Derecho de la Pontificia Universidad Católica de Valparaiso, no XLI, Valparaíso/Chile, 2013, $2^{\circ}$ semestre, p. 577-601. 
BOSCATTO, Muriele de Conto; MOSENA, Maurício. Decisão judicial democrática: o caminho entre o dever fundamental à fundamentação democrática e o direito fundamental à resposta constitucionalmente adequada ou hermeneuticamente desvelada. Revista Eletrônica Direito e Política, Programa de Pós-Graduação Stricto Sensu em Ciência Jurídica da UNIVALI, Itajaí, v.10, n.3, $2^{\circ}$ quadrimestre de 2015. Disponível em: www.univali.br/direitoepolitica - ISSN 1980-7791.

Outra problemática que vem sendo reiteradamente debatida pela doutrina strekiana e que é afim com as teorias que se constituíram no pós-positivismo ou no neoconstitucionalismo, também com o entrave do decisionismo e da discricionariedade, por assim, ao fundo, revelarem a manutenção do esquema sujeito-objeto, se trata da mal-interpretada ponderação, proposta, especialmente, pela doutrina de Robert Alexy.

Antes de avançar nessa discussão, vale lembrar que, inicialmente, falamos que muitas teorias que foram construídas com o objetivo de superar o positivismo acabaram resvalando no mesmo entrave desse modelo. $\mathrm{E}$ que entrave seria este? É justamente o do voluntarismo ou do triunfo da vontade: no positivismo exegético, a racionalidade, que se transporta na vontade do legislador; no positivismo normativista - porque o juiz produz norma -, do juiz. Quer dizer, sempre dependente do sujeito que assujeita o objeto.

No senso comum teórico ${ }^{29}$, pensar em positivismo significa pensar no positivismo exegético, ou seja, no juiz boca-da-lei. É também classificar Kelsen dentro destes positivistas, ignorando o "decisionismo" que assume em sua obra, ao admitir a interpretação como um ato de vontade. Streck ${ }^{30}$, outrossim, faz o corte, estreitando toda postura decisionista e discricionária - voluntarista - como característica de todo e qualquer positivismo, notadamente, da modalidade de positivismo que hoje impera, normativista, em razão daquilo que este Autor optou por chamar de "pan-principiologismo".

Abrindo parênteses, para tratar desse assunto "pan-principiologismo", importa frisar que, hoje, muito se fala na "era dos princípios constitucionais", o que fez com que parcela considerável da doutrina considerasse os princípios constitucionais como sucedâneo dos princípios gerais do direito ou como suporte dos valores da sociedade. Com a "positivação dos valores", como se costuma anunciar os princípios constitucionais, há uma facilitação da criação de todo tipo de "princípio", como se o paradigma do Estado Democrático de Direito desse o respaldo à legitimidade principiológica, "da qual pudessem ser retirados tantos

29 Fazendo menção ao termo desenvolvido pela doutrina de Luis Alberto Warat.

30 STRECK, LENIO. O que é isto - decido conforme minha consciência? 4. ed. Porto Alegre: Livraria do Advogado, 2013, p. 97-102. 
BOSCATTO, Muriele de Conto; MOSENA, Maurício. Decisão judicial democrática: o caminho entre o dever fundamental à fundamentação democrática e o direito fundamental à resposta constitucionalmente adequada ou hermeneuticamente desvelada. Revista Eletrônica Direito e Política, Programa de Pós-Graduação Stricto Sensu em Ciência Jurídica da UNIVALI, Itajaí, v.10, n.3, $2^{\circ}$ quadrimestre de 2015. Disponível em: www.univali.br/direitoepolitica - ISSN 1980-7791.

princípios quantos necessários para solver os casos difíceis ou 'corrigir' (sic) as incertezas da linguagem" ${ }^{\prime 31}$.

O que se tem visto, portanto, é o crescimento de um conjunto de álibis teóricos que vem recebendo convenientemente o nome de princípio. Assim, os "princípios" da simetria, da precaução, da não-surpresa, da afetividade, da verdade real, do livre convencimento do juiz, da cooperação processual, bem ainda da felicidade. Os citados "princípios" nada mais são do que a confissão da prevalência do esquema sujeito-objeto, através do que o intérprete lança mão para transportar a sua subjetividade à decisão judicial. Este também um dilema do "neoconstitucionalismo".

Fechado o parêntese, a diferença dos modelos positivistas - exegético e normativista ou o de antes e o de hoje -, é que agora não se realiza mais uma pirâmide formal de conceitos para apurar o sentido do direito positivo; ao revés, se utiliza do intérprete como canal através do qual os valores sociais invadem o direito. Destacamos aqui o papel que supostos "princípios" tem ganhado no cenário da escolha da decisão.

Nada obstante, os juristas que se colocam neste plano de subjetividade são obrigados a admitir múltiplas respostas na hora de decidir, já que, no campo da semântica, as palavras contêm incertezas designativas e significativas, a admitir uma pluralidade de sentidos. Daí falar-se em escolha do sentido, e não em decisão democrática.

É, nesse contexto, por exemplo, que se insere a ponderação alexyana, a qual iniciamos apontando não teria se livrado das amarras do positivismo normativista-, ao manter-se estreita ao esquema sujeito-objeto, próprio da filosofia da consciência. Para os casos fáceis, o nível da sintaxe resolveria o problema, ou seja, o exegetismo responderia o conflito surgido no âmbito das regras $^{32}$. Todavia, quando se estivesse diante de um caso difícil, Alexy apelaria

31 STRECK, Lenio Luiz; FERRAJOLI, Luigui; e TRINDADE, André Karam (org). Garantismo, Hermenêutica e (neo)constitucionalismo: um debate com Luigui Ferrajoli. Porto Alegre: Livraria do Advogado, 2012, p. 65.

32 Destacamos que, para Alexy (2011), o conflito de regras se resolve pelo método da subsunção ou mediante a inclusão de uma cláusula de exceção. Fala-se do critério tudo ou nada. Já a colisão entre princípios, pressupõe a aplicação da lei de colisão, o que determina a aplicação da fórmula peso. "O objetivo desse sopesamento é definir qual dos interesses - que abstratamente estão no mesmo nível - tem maior peso no caso concreto. A solução para esta colisão consiste no 
BOSCATTO, Muriele de Conto; MOSENA, Maurício. Decisão judicial democrática: o caminho entre o dever fundamental à fundamentação democrática e o direito fundamental à resposta constitucionalmente adequada ou hermeneuticamente desvelada. Revista Eletrônica Direito e Política, Programa de Pós-Graduação Stricto Sensu em Ciência Jurídica da UNIVALI, Itajaí, v.10, n.3, $2^{\circ}$ quadrimestre de 2015. Disponível em: www.univali.br/direitoepolitica - ISSN 1980-7791.

para outro nível da semiótica, qual seja, a pragmática. Quer dizer, a ponderação alexyana, desenvolvida para a resolução da colisão entre princípios, dependeria do sujeito e da sua subjetividade, abrindo espaço à malfadada discricionariedade, pelo uso da razão prática para corrigir as insuficiências do direito ${ }^{33}$.

O mais paradoxal é que a teoria alexyana foi desenvolvida para racionalizar a ponderação de valores. Ocorre que, no Brasil, os pressupostos formais racionalizadores são praticamente desconsiderados - basta ver as decisões levadas a efeito pelo Supremo Tribunal Federal, aplicando a proporcionalidade alexyana, pelo simples sopesamento dos interesses: "entre dois princípios que colidem, o intérprete escolhe $\mathrm{um}^{\prime{ }^{34}}$-, retornando às estratégias da fundamentação da jurisprudência da valoração.

Com efeito, quando Dworkin ataca o positivismo, não está se dirigindo ao positivismo exegético, mas sim ao positivismo que coloca na discricionariedade ou na vontade - do intérprete o poder de estabelecer os sentidos jurídicos.

Destarte, o drama da discricionariedade é que ela transforma os juízes em legisladores. Falsamente superamos o positivismo, mas, na verdade, substituímos o formalismo racionalista, que traz por de fundo a vontade do legislador, porém, colocamos em seu lugar o voluntarismo judicial, permanecendo o direito na alçada da vontade do poder de Kelsen.

Mais, o poder discricionário propicia a criação do próprio objeto de conhecimento, típica problemática que remete a questão ao solipsismo característico da filosofia da consciência. Ou seja, concebe-se a razão humana como fonte iluminadora do significado de tudo o que pode ser enunciado sobre a realidade.

Portanto,

[...] o ponto fulcral não está nem no exegetismo, nem no positivismo fático [...] e tampouco nas teorias que apostam na argumentação jurídica como um passo para além da retórica e como um modo de corrigir as insuficiências do

estabelecimento de uma relação de precedência condicionada entre princípios, com base nas circunstâncias do caso concreto" (Alexy, 2011, p. 95-96).

33 STRECK, Lenio Luiz. Jurisdição constitucional e decisão jurídica. 3. ed. São Paulo: Revista dos Tribunais, 2013, p. 203-206.

34 Merece ser destacado que a tese da ponderação proposta por Alexy não envolve essa escolha direta. 
BOSCATTO, Muriele de Conto; MOSENA, Maurício. Decisão judicial democrática: o caminho entre o dever fundamental à fundamentação democrática e o direito fundamental à resposta constitucionalmente adequada ou hermeneuticamente desvelada. Revista Eletrônica Direito e Política, Programa de Pós-Graduação Stricto Sensu em Ciência Jurídica da UNIVALI, Itajaí, v.10, n.3, $2^{\circ}$ quadrimestre de 2015. Disponível em: www.univali.br/direitoepolitica - ISSN 1980-7791.

direito legislado. Na verdade, o problema, em qualquer das teses que procuram resolver o problema de como se interpreta e como se aplica, localiza-se no sujeito da modernidade, isto é, no sujeito da subjetividade assujeitadora, objeto da ruptura ocorrida no campo da filosofia pelo giro linguístico-ontológico e que não foi recepcionado pelo direito ${ }^{35}$.

E é aqui que consiste o papel da hermenêutica: "Parar de dizer obviedades, [...] e enfrentar de frente o problema representado pelo 'triunfo da vontade ${ }^{\prime \prime \prime 36}$, construindo o espaço no qual se possa fundamentar adequada e constitucionalmente a decisão judicial, livre que está tanto das amarras desse sujeito onde reside a razão prática como daquelas posturas que buscam substituir esse sujeito por estruturas ou sistemas.

Resgatando novamente a problemática "pan-principiológica", que se origina da equivocada ideia de que os "princípios" proporcionariam uma abertura interpretativa, mediante a qual o intérprete destes axiomas se valeria para direcionar a decisão judicial no sentido da sua subjetividade, adverte Streck (2012):

[...] torna-se necessário uma filtragem hermenêuticoconstitucional nesse universo de standards e critérios com pretensões de normatividade, localizando-se, na maior parte das vezes, em uma zona de arbitrariedade significativa, ficando estes a dever a comunidade jurídica uma fundamentação/justificação consistente ${ }^{37}$.

A grande discussão que ronda o Constitucionalismo Contemporâneo, então, considerando a concepção de Estado Democrático de Direito e o papel transformador assumido pelo Direito neste cenário e de cujo protagonismo

35 STRECK, Lenio. Jurisdição e ausência de uma teoria da decisão. Revista de Derecho de la Pontificia Universidad Católica de Valparaiso, no XLI, Valparaíso/Chile, 2013, 20 semestre, p. 595.

36 STRECK, Lenio Luiz. Jurisdição constitucional e decisão jurídica. 3. ed. São Paulo: Revista dos Tribunais, 2013, p. 206.

37 STRECK, Lenio Luiz; FERRAJOLI, Luigui; e TRINDADE, André Karam (org). Garantismo, Hermenêutica e (neo)constitucionalismo: um debate com Luigui Ferrajoli. Porto Alegre: Livraria do Advogado, 2012, p. 71. 
BOSCATTO, Muriele de Conto; MOSENA, Maurício. Decisão judicial democrática: o caminho entre o dever fundamental à fundamentação democrática e o direito fundamental à resposta constitucionalmente adequada ou hermeneuticamente desvelada. Revista Eletrônica Direito e Política, Programa de Pós-Graduação Stricto Sensu em Ciência Jurídica da UNIVALI, Itajaí, v.10, n.3, $2^{\circ}$ quadrimestre de 2015. Disponível em: www.univali.br/direitoepolitica - ISSN 1980-7791.

assume o Judiciário, através da figura do juiz, fica por conta da questão envolta do subjetivismo - ou da manutenção do esquema sujeito-objeto -, no ato de proferir a decisão que assim deve se coadunar com o paradigma constitucional.

Bem percebemos que, em muitos discursos, fica clara a noção de escolha, e não de "decisão democrática", a qual pressupõe "fundamentação democrática", para resultar na resposta correta, consistente na "resposta constitucionalmente adequada ou hermeneuticamente desvelada", ambos ganhando a nota da fundamentalidade material, conforme antes demonstrado. E é aqui que queremos fechar nosso ensaio neste título: no caminho para esta resposta, donde nos remetemos aos referenciais teóricos de Streck, ou seja, à hermenêutica filosófica de Gadamer e a teoria integrativa do direito de Dworkin.

De acordo com Streck,

Gadamer [...] faz uma ruptura com o método a partir da superação do esquema sujeito-objeto, confrontando-se, abertamente, com o sujeito solipsista ('Selbstsüchtiger') da modernidade. [...] coloca a autoridade da tradição, a aferição da verdade hermenêutica a partir dos pré-juízos legítimos e ilegítimos, circunstância que reforça a relação da hermenêutica para com o direito, mormente pelo locus privilegiado representado pela Constituição ${ }^{38}$.

A hermenêutica não vai abrir mão do sujeito da relação, enfim, do sujeito que lida com objetos. O que ela supera é o esquema sujeito-objeto, responsável pelo sujeito solipsista que sustenta as posturas subjetivistas-axiologistas da maioria das teorias do direito mesmo deste século. Na hermenêutica, portanto, há um efetivo controle da interpretação, a partir da tradição, da obrigação de coerência, da integridade, da igualdade, da isonomia, enfim, através da incorporação dos princípios constitucionais, que se pode chamar de "virtudes soberanas". Por isso, "os discursos predadores do direito são rechaçados por esta blindagem hermenêutica que protege o direito produzido democraticamente" ${ }^{39}$.

38 STRECK, Lenio. Jurisdição e ausência de uma teoria da decisão. Revista de Derecho de la Pontificia Universidad Católica de Valparaiso, no XLI, Valparaíso/Chile, 2013, 20 semestre, p. 591.

39 STRECK, Lenio Luiz; FERRAJOLI, Luigui; e TRINDADE, André Karam (org). Garantismo, Hermenêutica e (neo)constitucionalismo: um debate com Luigui Ferrajoli. Porto Alegre: Livraria do Advogado, 2012, p. 79. 
BOSCATTO, Muriele de Conto; MOSENA, Maurício. Decisão judicial democrática: o caminho entre o dever fundamental à fundamentação democrática e o direito fundamental à resposta constitucionalmente adequada ou hermeneuticamente desvelada. Revista Eletrônica Direito e Política, Programa de Pós-Graduação Stricto Sensu em Ciência Jurídica da UNIVALI, Itajaí, v.10, n.3, $2^{\circ}$ quadrimestre de 2015. Disponível em: www.univali.br/direitoepolitica - ISSN 1980-7791.

E é, por isso, também que se pode sustentar respostas adequadas à Constituição, e, assim, apostar também numa teoria da decisão, e não apenas da legislação. Múltiplas respostas dizem com um relativismo umbilicalmente relacionado às posturas positivistas, na medida em que abre à discricionariedade judicial.

Nas palavras de Nascimento,

$\mathrm{O}$ atual momento em que se encontra o direito constitucional necessita de meios para adquirir efetividade. Nesse passo, verifica-se a utilização da hermenêutica, que trabalha com o dar sentido ao texto jurídico, com o Daisen (ser-aí). Essa nova forma de exegese busca retirar o véu que encobre os operadores jurídicos, objetivando o 'des' velamento (alétheia) da aplicação do direito ao caso em concreto ${ }^{40}$.

É nesse caminho que se defende a Crítica Hermenêutica do Direito ou Nova Crítica do Direito, para a busca da nossa "fundamentação democrática" ou ainda à satisfação do direito e/ou dever fundamental de fundamentação. Quer dizer, através da análise fenomenológica, permitir o desvelamento daquilo que, no comportamento cotidiano, é ocultado, o exercício da transcendência, no qual não aparece o ser, mas também o ser-aí, o ser-no-mundo, em homenagem a Heidegger. Onde mais: "O processo interpretativo deixa de ser reprodutivo e passa a ser produtivo, onde a linguagem deixa de ser um instrumento, uma terceira coisa que se interpõe entre sujeito e o objeto, passando a ser condição de possibilidade."41

\section{DA CONCRETIZAÇÃO DO DIREITO FUNDAMENTAL A UMA RESPOSTA CONSTITUCIONALMENTE ADEQUADA OU HERMENEUTICAMENTE DESVELADA: PONTO DE CHEGADA À "DECISÃO DEMOCRÁTICA"}

\footnotetext{
40 NASCIMENTO, Valéria Ribas do. A filosofia hermenêutica para uma jurisdição constitucional democrática: fundamentação/aplicação da norma jurídica na contemporaneidade. Revista Direito GV. São Paulo, p. 147-168, jan./jun. 2009, 154-155.

41 NASCIMENTO, Valéria Ribas do. A filosofia hermenêutica para uma jurisdição constitucional democrática: fundamentação/aplicação da norma jurídica na contemporaneidade. Revista Direito GV. São Paulo, p. 147-168, jan./jun. 2009, p. 162.
} 
BOSCATTO, Muriele de Conto; MOSENA, Maurício. Decisão judicial democrática: o caminho entre o dever fundamental à fundamentação democrática e o direito fundamental à resposta constitucionalmente adequada ou hermeneuticamente desvelada. Revista Eletrônica Direito e Política, Programa de Pós-Graduação Stricto Sensu em Ciência Jurídica da UNIVALI, Itajaí, v.10, n.3, $2^{\circ}$ quadrimestre de 2015. Disponível em: www.univali.br/direitoepolitica - ISSN 1980-7791.

Apresentada a hermenêutica filosófica como matriz adequada à busca ou a realização do direito e/ou dever fundamental de fundamentação - desvinculada a perspectiva de uma proposta metodológica, a final, "verdade é contra o método", no referencial gadameriano-, nos cabe ainda, dentro dos limites do presente estudo, estreitar a nossa "fundamentação democrática" com a resposta constitucionalmente adequada ou, se assim se queira, hermeneuticamente desvelada, representando o resultado final do nosso percurso à decisão democrática.

No contexto do paradigma constitucional, como adiante sustentamos, certo é que a escolha do sentido do texto não pode ficar relegada à conveniência do intérprete. Noutro viés, a "decisão democrática" que viemos construindo não pode ser o resultado de escolhas majoritárias ou de convencionalismos. Isso é próprio de paradigmas superados, que encobrem posturas positivistas, a permitirem a discricionariedade e o decisionismo.

Defender esse voluntarismo implica dizer que o direito esta autorizado a amparar soluções divergentes a um mesmo caso, dentre as quais o juiz escolhe a que lhe parece moralmente mais apropriada - como se a moral corrigisse o direito - ou socialmente mais útil - como se o direito se relacionasse diretamente com a razão prática e ainda como se, primeiro, se decidisse para depois se justificar essa posição (escolha).

Tratar da "decisão democrática" implica contextualizar a problemática na perspectiva dos direitos e deveres fundamentais, ou seja, no cerne do Constitucionalismo Contemporâneo: a democracia. Toda decisão é um ato de poder e, se este poder não estiver completamente legitimado, isto é, embasado em pressupostos constitucionais, estar-se-á diante de um poder ilegítimo, arbitrário.

Logo, no âmbito do Estado Democrático de Direito, não se admite decisão "meio" fundamentada e nem a resposta que não seja adequada, como resultado desse processo. Outrossim, a decisão, devida e democraticamente fundamentada, alcançará a resposta correta ou constitucionalmente adequada, ultimando com a realização dos dever e direito fundamentais que aqui referenciamos.

Desde quando se reconhece a diferença entre texto e norma - quer dizer, que o texto não compreende a extensão do conteúdo linguístico da norma, embora 
BOSCATTO, Muriele de Conto; MOSENA, Maurício. Decisão judicial democrática: o caminho entre o dever fundamental à fundamentação democrática e o direito fundamental à resposta constitucionalmente adequada ou hermeneuticamente desvelada. Revista Eletrônica Direito e Política, Programa de Pós-Graduação Stricto Sensu em Ciência Jurídica da UNIVALI, Itajaí, v.10, n.3, $2^{\circ}$ quadrimestre de 2015. Disponível em: www.univali.br/direitoepolitica - ISSN 1980-7791.

façam parte de um mesmo todo -, e que a fundamentação parte do reconhecimento da diferença ontológica - a partir do que a hermenêutica cinde o juízo apofântico do hermenêutico -, os sentidos se dão intersubjetivamente. A diferença ontológica é o elemento do ser-aí-no-mundo, pressupondo antecipação de sentido, revelada pela pré-compreensão, que é colocada à prova pela tradição e a noção de integridade e de coerência do direito, caminhando ao alcance da compreensão autêntica.

[...] Gadamer [...] reconstrói a estrutura ontológica do círculo hermenêutico heideggeriano. Destaca-se que a categoria do círculo hermenêutico ou do sentido reduplicado, é de fundamental importância para o direito e para jurisdição constitucional, pois a premissa filosófica demonstra que a história, a cultura e a tradição já estão na estrutura da compreensão do interprete, formando uma circularidade [...]. Isso sublinha a necessidade de fundamentação do julgador para se atingir a resposta hermeneuticamente adequada em cada processo. ${ }^{42}$

Assim é que a hermenêutica - e a sua circularidade - permite alcançar a resposta adequada à Constituição, na hipótese concreta. Segundo Streck, não se trata simplesmente de aderir à tese da única resposta certa proposta por Dworkin. "Não será a única resposta - será, sim, 'a' resposta"43, isto é, uma resposta que deve ser confirmada na própria Constituição.

Estreitos ao dever fundamental de fundamentação e ao direito fundamental à resposta constitucionalmente adequada (correta) estão os princípios - virtudes da integridade e coerência do direito. São eles que, no âmbito da Crítica Hermenêutica do Direito, com destaque à ínsita tradição, conduzirão à resposta correta.

A decisão judicial democrática, portanto, não exsurgirá do balanceamento que o intérprete faz entre supostos valores em colisão, mas, sim, da reconstrução do direito, em respeito à integridade e à coerência da questão jurídica em debate.

\footnotetext{
42 NASCIMENTO, Valéria Ribas do. A filosofia hermenêutica para uma jurisdição constitucional democrática: fundamentação/aplicação da norma jurídica na contemporaneidade. Revista Direito GV. São Paulo, p. 147-168, jan./jun. 2009, p. 153-154.

43 STRECK, Lenio Luiz. Jurisdição constitucional e decisão jurídica. 3. ed. São Paulo: Revista dos Tribunais, 2013, p. 316.
} 
BOSCATTO, Muriele de Conto; MOSENA, Maurício. Decisão judicial democrática: o caminho entre o dever fundamental à fundamentação democrática e o direito fundamental à resposta constitucionalmente adequada ou hermeneuticamente desvelada. Revista Eletrônica Direito e Política, Programa de Pós-Graduação Stricto Sensu em Ciência Jurídica da UNIVALI, Itajaí, v.10, n.3, $2^{\circ}$ quadrimestre de 2015. Disponível em: www.univali.br/direitoepolitica - ISSN 1980-7791.

Aos juízes se imputará a responsabilidade política enfatizada por Dworkin, responsabilidade para com o resgate da tradição, dos princípios constitucionais ou das questões de princípio postas à discussão, da doutrina e mesmo dos julgados já proferidos sobre a temática. A partir disso, colocando todo este arcabouço à prova da Constituição, que, ao fim e ao cabo, conduzirá ao desvelamento do sentido do direito em liça.

Portanto, o sentido hermeneuticamente adequado se obtém das concretas decisões por essa integração coerente na prática jurídica, assumindo especial importância a autoridade da tradição.

Assim é que

essa resposta (decisão) ultrapassa o raciocínio causalexplicativo, buscando no ethos principiológico a fusão de horizontes demandada pela situação que se apresenta. Antes de qualquer outra análise, deve-se sempre perquirir a compatibilidade constitucional da norma jurídica com a constituição (entendida, à evidência, no seu todo principiológico) e a existência de eventual antinomia. Devese perguntar se, à luz dos princípios e dos preceitos constitucionais, a norma é aplicável à hipótese (ao caso). Mais ainda, há que se indagar em que sentido aponta a précompreensão (Vorverständnis), condição para compreensão do fenômeno. Para interpretar, é necessário, primeiro, compreender (verstehen) o que se quer interpretar. Este "estar diante" de algo (verstehen) é condição de possibilidade do agir dos juristas: a Constituição. A decisão constitucionalmente adequada é a applicatio (superada, portanto, a cisão do ato interpretativo em conhecimento, interpretação e aplicação). ${ }^{44}$

Tal responsabilidade política se traduz no próprio dever fundamental à fundamentação democrática que defendemos, através da regra do art. 93, IX, da Carta Constitucional de1988. Lá se encontra a normativa que exige que o juiz explicite as condições pela qual compreendeu, sendo que o resultado desta compreensão é a aplicação do direito fundamental à resposta constitucionalmente adequada ou, se assim se quer, hermeneuticamente desvelada.

\footnotetext{
${ }^{44}$ STRECK, Lenio Luiz. Jurisdição constitucional e decisão jurídica. 3. ed. São Paulo: Revista dos Tribunais, 2013, p. 343.
} 
BOSCATTO, Muriele de Conto; MOSENA, Maurício. Decisão judicial democrática: o caminho entre o dever fundamental à fundamentação democrática e o direito fundamental à resposta constitucionalmente adequada ou hermeneuticamente desvelada. Revista Eletrônica Direito e Política, Programa de Pós-Graduação Stricto Sensu em Ciência Jurídica da UNIVALI, Itajaí, v.10, n.3, $2^{\circ}$ quadrimestre de 2015. Disponível em: www.univali.br/direitoepolitica - ISSN 1980-7791.

É condição de possibilidade da decisão jurídica o fundamento do compreendido. E isso quer significar que a historicidade da compreensão - ou a reconstrução do direito, como exigência da integridade e coerência, através daquilo que ganha relevo sob o nome de tradição, na hermenêutica - se apresenta como elemento fundamental do dever de fundamentação da decisão, revelando-se, ao mesmo tempo, como pressuposto do princípio do direito fundamental a uma resposta constitucionalmente adequada.

Pela observância do dever e do corelato direito decorrentes da fundamentação democrática que viemos defendendo neste estudo, se tem a superação dos resquícios de paradigmas passados, como a prática da subsunção ou do silogismo-dedutivista.

A necessidade da fundamentação nos moldes apresentados impede que as decisões se resumam à citação de enunciados assertóricos e anti-hermenêuticos. Isso quer dizer que fica afastada a possibilidade de se dizer que o juiz primeiro decide e depois encontra "fundamento" para sua opção.

Reconhecer mais o direito fundamental à resposta correta - ou constitucionalmente adequada - significa substituir qualquer pretensão solipisita pelas condições histórico-concretas, sempre com destaque à tradição, respaldada pelas noções de integridade e coerência do direito.

Nesse caminho, o dever e o direito fundamentais que emanam da fundamentação democrática estão aptos à superação do principal problema evidenciado pelo Constitucionalismo Contemporâneo: o predomínio da relação sujeito-objeto.

Nessa medida, Streck coloca que "o direito fundamental a uma resposta adequada à Constituição, [...] é um 'produto' filosófico, porque caudatário de um novo paradigma que ultrapassa o esquema sujeito-objeto $[\ldots]^{\prime \prime 45}$.

Portanto, para além da cisão estrutural entre os casos simples e os casos difíceis, pensar na decisão judicial democrática pressupõe o reconhecimento dos direito e dever fundamentais estreitos à fundamentação também qualificada por democrática, a qual se constrói em um todo coerente de princípios

\footnotetext{
${ }^{45}$ STRECK, Lenio Luiz. Jurisdição constitucional e decisão jurídica. 3. ed. São Paulo: Revista dos Tribunais, 2013, p. 344.
} 
BOSCATTO, Muriele de Conto; MOSENA, Maurício. Decisão judicial democrática: o caminho entre o dever fundamental à fundamentação democrática e o direito fundamental à resposta constitucionalmente adequada ou hermeneuticamente desvelada. Revista Eletrônica Direito e Política, Programa de Pós-Graduação Stricto Sensu em Ciência Jurídica da UNIVALI, Itajaí, v.10, n.3, $2^{\circ}$ quadrimestre de 2015. Disponível em: www.univali.br/direitoepolitica - ISSN 1980-7791.

constitucionais que repercutem a história institucional do direito. Nessa direção, é superado o voluntarismo, que anda de mãos dadas com a arbitrariedade, e preservada a função principal do direito nesta quadra da história: a preservação da democracia.

\section{CONSIDERAÇÕES FINAIS}

Por tudo o que apresentamos neste ensaio, algumas premissas conclusivas se extraem. Metodologicamente, trabalharemos com as três perspectivas que conduziram o desenrolar do estudo, tecendo nossas considerações finais.

Primeiramente, o reconhecimento dos dever e direito fundamentais correlatos à fundamentação democrática, quais sejam, à própria fundamentação desta natureza e à resposta constitucionalmente adequada, como premissa básica ou ponto de partida à "decisão democrática". Noutras palavras, precisamos da teoria dos direitos fundamentais, inclusive, do efeito proporcionado pelo dever de proteção, para respaldar a perspectiva da validade da decisão, no âmbito do Estado Democrático de Direito, a partir da concretização destes dever e direito fundamentais.

Num segundo momento, a extensão ou o referencial da Crítica Hermenêutica do Direito, demonstrando o modus operandi ou o "como" se alcançar a satisfação destes dever e direito fundamentais pressupostos da decisão democrática.

Nesta segunda linha de organização das ideias, partimos da concepção de Estado Democrático de Direito, estreitando esta noção a da concretização dos direi tos e deveres fundamentais e, assim, a de democracia, para, a partir disso, questionarmos as teorias que se surgiram, no "neoconstitucionalismo", com o desiderato de satisfazer estes direitos e deveres fundamentais, porém apostando na subjetividade do intérprete, na condição deste espelhar-se em valores morais supostamente capazes de corrigir o direito.

Acusamos que o grande problema do Constitucionalismo Contemporâneo - termo que optamos por utilizar no artigo ao invés do neoconstitucionalismo eivado de dificuldades interpretativas - não está exatamente no resgate do exegetismo ou mesmo no normativismo (modelos positivistas que, respectivamente, encontram na lei e no juiz o sentido da norma). Mas, encontra-se na não superação 
BOSCATTO, Muriele de Conto; MOSENA, Maurício. Decisão judicial democrática: o caminho entre o dever fundamental à fundamentação democrática e o direito fundamental à resposta constitucionalmente adequada ou hermeneuticamente desvelada. Revista Eletrônica Direito e Política, Programa de Pós-Graduação Stricto Sensu em Ciência Jurídica da UNIVALI, Itajaí, v.10, n.3, $2^{\circ}$ quadrimestre de 2015. Disponível em: www.univali.br/direitoepolitica - ISSN 1980-7791.

paradigmática da filosofia da consciência que marcou a modernidade e o seu sujeito produtor ou iluminador dos sentidos das coisas.

Noutras palavras, percebemos que as teorias que se surgiram neste patamar da história constitucional, cuja orientação deveria se dar pela perspectiva do Estado Democrático de Direito, permitem e, por vezes, defendem discricionariedades e decisionismos, porta de entrada para o voluntarismo e a conclusão do predomínio da vontade do sujeito, na decisão, ou, se assim se queira, na manutenção da relação sujeito-objeto própria do paradigma passado (filosofia da consciência).

Ainda neste mesmo contexto, trazemos à lume a hermenêutica, em especial, a Crítica Hermenêutica do Direito, como apta a esta superação paradigmática, eis que livre do sujeito que assujeita o objeto. Apostamos, então, na tradição, com o resgate histórico-jurídico do direito em liça, em cotejo com o norte da Constituição, para produzir o sentido do direito ao caso em debate.

Nessa perspectiva, avançamos para a terceira linha de raciocínio e que finaliza a nossa "decisão democrática": o direito fundamental à resposta constitucionalmente adequada ou hermeneuticamente desvelada.

Nesse último ponto, nos valemos da responsabilidade política do intérprete, bem defendida pela doutrina de Dworkin, para, através das virtudes da integração e da coerência, que corresponde ao que a hermenêutica chama de tradição, sempre em consonância ao texto constitucional, satisfazer seu dever fundamental de fundamentação democrática e, nessa linha, alcançar/aplicar o direito fundamental à resposta correta.

Como se pode observar, pretendemos percorrer um caminho à decisão que chamamos de democrática, ou seja, à decisão judicial própria do paradigma constitucional vigente. Essa decisão tem um início com o reconhecimento da fundamentalidade dos dever de fundamentação democrática e direito à resposta correta. Tem um "meio" (nunca pretendendo ser um método) de alcançá-la, para o que invocamos a Crítica Hermenêutica do Direito. Tem ainda um fim: a resposta correta, para a situação em debate.

Seguindo esse percurso, fugimos da escolha subjetiva do intérprete, que, por vezes, primeiro, elege o interesse que the parece mais adequado, para, depois, justificar essa opção; e avançamos à decisão democrática que precisamos no 
BOSCATTO, Muriele de Conto; MOSENA, Maurício. Decisão judicial democrática: o caminho entre o dever fundamental à fundamentação democrática e o direito fundamental à resposta constitucionalmente adequada ou hermeneuticamente desvelada. Revista Eletrônica Direito e Política, Programa de Pós-Graduação Stricto Sensu em Ciência Jurídica da UNIVALI, Itajaí, v.10, n.3, $2^{\circ}$ quadrimestre de 2015. Disponível em: www.univali.br/direitoepolitica - ISSN 1980-7791.

âmbito do Estado Democrático de Direito. Noutras palavras, aplaudimos a democracia e repulsamos a vontade do poder!

\section{REFERÊNCIAS DAS FONTES CITADAS}

ALEXY, Robert. Teoria dos direitos fundamentais. Trad. Virgílio Afonso da Silva. $2^{a}$ ed. $3^{a}$ tir. São Paulo: Malheiros, 2011.

ANDRADE, José Carlos Vieira de. Os direitos fundamentais na constituição portuguesa de 1976. Coimbra: Livraria Almedina, 1987, apud SARLET, Ingo Wolfgang. A eficácia dos direitos fundamentais: uma teoria geral dos direitos fundamentais na perspectiva constitucional. 11 ed. rev. atual. Porto Alegre: Livraria do Advogado Editora, 2012.

CANOTILHO, Joaquim José Gomes. Direito Constitucional e Teoria da Constituição. $3^{a}$ ed. Coimbra: Coimbra Editora, 1999.

GRIMM, Dieter. A função protetiva do Estado. In SOUZA NETO, Cláudio Pereira de. E SARMENTO, Daniel (Coord.). A constituição do direito: fundamentos teóricos e aplicações específicas. Rio de Janeiro: Lumen Juris, 2007, p. 149-165.

NASCIMENTO, Valéria Ribas do. A filosofia hermenêutica para uma jurisdição constitucional democrática: fundamentação/aplicação da norma jurídica na contemporaneidade. Revista Direito GV. São Paulo, p. 147-168, jan./jun. 2009.

NOVAIS, Jorge Reis. Direitos fundamentais e justiça constitucional em estado democrático de direito. $1^{\text {a }}$ ed. Coimbra: Coimbra Editora, 2012.

SARLET, Ingo Wolfgang. A eficácia dos direitos fundamentais: uma teoria geral dos direitos fundamentais na perspectiva constitucional. 11 ed. rev. atual. Porto Alegre: Livraria do Advogado Editora, 2012.

STRECK, Lenio Luiz. Jurisdição constitucional e decisão jurídica. 3. ed. São Paulo: Revista dos Tribunais, 2013.

Jurisdição constitucional e hermenêutica: perspectivas e possibilidades de concretização dos direitos fundamentais-sociais no Brasil. Novos Estudos Jurídicos. v. 8. no 2. p. 257-301, mai./ago. 2003. Disponível em <http://siaiweb06.univali.br/seer/index.php/nej/article/view/336/280>； Acesso em 14 jul. 2014.

Verdade e consenso: constituição, hermenêutica e teorias discursivas. 5 ed. São Paulo: Saraiva, 2014.

Lições de crítica hermenêutica do direito. 1 ed. Porto Alegre: Livraria do Advogado, 2014. 
BOSCATTO, Muriele de Conto; MOSENA, Maurício. Decisão judicial democrática: o caminho entre o dever fundamental à fundamentação democrática e o direito fundamental à resposta constitucionalmente adequada ou hermeneuticamente desvelada. Revista Eletrônica Direito e Política, Programa de Pós-Graduação Stricto Sensu em Ciência Jurídica da UNIVALI, Itajaí, v.10, n.3, $2^{\circ}$ quadrimestre de 2015. Disponível em: www.univali.br/direitoepolitica - ISSN 1980-7791.

Hermenêutica jurídica $\mathbf{e}(\mathbf{m})$ crise: uma exploração hermenêutica da construção do direito. 8 ed. Porto Alegre: Livraria do Advogado, 2009.

O que é isto - decido conforme minha consciência? 4. ed. Porto Alegre: Livraria do Advogado, 2013.

O Solipsismo Hermenêutico e os Obstáculos à Concretização da Constituição no Brasil. In: Direitos Fundamentais e Democracia Constitucional. Org. TRINDADE, André Karam et all (Org.). Florianópolis: Conceito Editora, 2013, p. 19-66.

. Jurisdição e ausência de uma teoria da decisão. Revista de Derecho

de la Pontificia Universidad Católica de Valparaiso, no XLI, Valparaíso/Chile, 2013, $2^{\circ}$ semestre, p. 577-601.

O problema da decisão jurídica em tempos pós-positivistas. NEJ. Vol 14, n. 2, 20 quadrimestre de 2009, p. 3-26.

STRECK, Lenio Luiz; FERRAJOLI, Luigui; e TRINDADE, André Karam (org). Garantismo, Hermenêutica e (neo)constitucionalismo: um debate com Luigui Ferrajoli. Porto Alegre: Livraria do Advogado, 2012.

QUEIROZ, Cristina M. M. Direitos fundamentais: teoria geral. 2 ed. Coimbra: Coimbra Editora, 2010.

Submetido em: Maio/2015

Aprovado em: Julho/2015 